\title{
REFORMING THE FILIBUSTER
}

Filibusters are a necessary evil, which must be tolerated lest the Senate lose its special strength and become a mere appendage of the House of Representatives. ${ }^{\dagger}$

The House of Lords is not the watchdog of the constitution; it is Mr. Balfour's poodle. ${ }^{*}$

INTRODUCTION 303

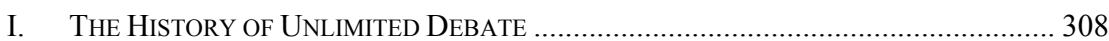

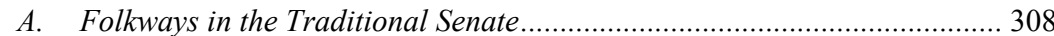

B. The Two-Track System and Supermajority Rule ……………………........ 313

II. A SUSPENSORY Veto AND THE House OF LoRdS ................................................. 316

A. A Compromise Proposal ............................................................................ 317

B. Drawing on the British Parliamentary Experience ................................... 319

III. MAKing The Senate SeE The Light ............................................................... 323

A. Native Americans, Elections, and Treaties................................................ 324

B. Unconventional Action and the Filibuster ................................................ 327

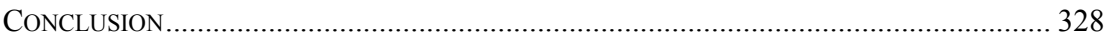

\section{INTRODUCTION}

The most troubling countermajoritarian difficulty in modern constitutional law is Rule XXII of the United States Senate. ${ }^{1}$ Forty-one senators,

\footnotetext{
* Professor of Law, Indiana University School of Law-Indianapolis. Many thanks to Carlo Andreani, Aaron Bruhl, Josh Chafetz, Dan Cole, and Mike Pitts for their excellent comments.

† Gregory J. WaWro \& ERIC SChickler, Filibuster: ObStruction and LaWMaking IN the U.S. SENATE 7 (2006) (quoting Senator Robert C. Byrd).

‡ Roy Jenkins, Mr. Balfour's Poodle: PeErs V. People 10, $42-44$ (1954) (quoting Prime Minister David Lloyd George attacking the veto held by the House of Lords prior to the Parliament Act of 1911 by noting that the peers were acting in a partisan fashion to support the Tory opposition leader in the House of Commons).

${ }^{1}$ See Alexander M. Bickel, The Least Dangerous Branch: The Supreme Court at the BAR OF POLITICS 16 (2d ed. 1986) (coining "counter-majoritarian difficulty" to describe judicial review); see also U.S. SenAte Comm. On Rules And Admin., Standing Rules of the Senate, S. Doc. No. 110-9, at 16-17 (2007) (Rule XXII(2)), available at http://rules.senate.gov/public/index.cfm? $\mathrm{p}=$ RuleXXII (stating that on most questions whether a Senate debate "shall be brought to a close[] ...
} 
who could represent less than forty-one percent of the population due to the malapportionment of the Senate, ${ }^{2}$ can veto most legislation and presidential nominations by refusing to invoke cloture. A vote against cloture by that Senate minority sustains debate indefinitely as a filibuster. Although the filibuster is woven into our political folklore and critical to the legislative process, few legal scholars have examined the practice. ${ }^{3}$ This lack of interest is surprising because the presumption that a supermajority is required for most Senate action is a recent development that casts a shadow over democratic self-government. ${ }^{4}$

This Essay evaluates the tradition of unlimited debate in the Senate and argues that a refusal to vote for cloture should result in a suspensory rather

shall be decided ... by three-fifths of the Senators duly chosen and sworn" (internal quotation mark omitted)).

${ }^{2}$ See U.S. CONST. art. I, § 3, cl. 1 ("The Senate of the United States shall be composed of two Senators from each State ...."). The structure of the Senate is clearly contrary to the Supreme Court's "oneperson, one-vote" decisions. See Reynolds v. Sims, 377 U.S. 533, 574 (1964) (rejecting the federal analogy to the apportionment of state legislatures because "[t]he system of representation in the two Houses of the Federal Congress is one ingrained in our Constitution, as part of the law of the land. It is one conceived out of compromise and concession indispensable to the establishment of our federal republic."). It is also possible that forty-one senators can represent more than fifty percent of the population, thus one cannot say that the filibuster is always countermajoritarian.

${ }^{3}$ See Sarah A. Binder \& Steven S. Smith, Politics or Principle? Filibustering in the UNITED STATES SENATE 1 (1997) ("Perhaps no feature of legislative procedure has received more attention - and less scrutiny - than the Senate filibuster."); Catherine Fisk \& Erwin Chemerinsky, The Filibuster, 49 STAN. L. REV. 181, 183 (1997) ("[L]egal scholars have paid only limited attention to the filibusters."); Michael J. Gerhardt, The Constitutionality of the Filibuster, 21 CONST. COMMENT. 445, 446 (2004) ("[V]ery few legal scholars have devoted serious attention to the filibuster."); cf. MR. SMITH Goes to WASHINGTON (Columbia Pictures 1939) (glamorizing the filibuster). There are exceptions to the cloture rule, most notably in the reconciliation process that governs the federal budget. See 2 U.S.C. $\S 907$ (b)-(d) (2006); Fisk \& Chemerinsky, supra, at 215 ("Under the congressional legislation governing the budget, all budget reconciliation legislation is considered under procedural rules that strictly limit the time for debate and other procedural delay. Reconciliation bills cannot be filibustered because the time for debate is strictly limited by statute." (footnote omitted)).

The fact that sweeping health care was enacted in 2010 via reconciliation does not eliminate the need for filibuster reform. That result was possible only because the Senate invoked cloture and approved the initial version of the bill when Democrats had sixty votes. After that, both houses passed a separate reconciliation bill to smooth over the differences between the two chambers. This kind of political conjunction is rare.

${ }^{4}$ See WAWRO \& SCHICKLER, supra note $\dagger$, at 157 ("In the contemporary Senate, with the exception of budget legislation and other bills where statutory requirements restrict minority obstruction, it is safe to assume that a $60 \%$ majority is generally necessary to adopt major legislation. In the pre-cloture Senate, no such assumption appears appropriate."); Fisk \& Chemerinsky, supra note 3, at 199 ("[F]rom the late 1920s until the late 1960s, the filibuster became almost entirely associated with the battle over civil rights" and was not used on other issues.); Gerhardt, supra note 3, at 452 (pointing out that Senate liberals opposed the filibuster on principle during the civil rights era).

The President can circumvent filibusters of his nominees to some extent by making recess appointments. U.S. CONST. art. II, $\S 2$, cl. 3 ("The President shall have Power to fill up all Vacancies that may happen during the Recess of the Senate, by granting Commissions which shall expire at the End of their next Session.”). The Senate, however, can block this maneuver by holding nominal sessions every day (e.g., for two minutes). There cannot be a recess appointment without a recess. 
than an absolute veto. ${ }^{5}$ In other words, forty-one senators should be able to extend debate on bills or nominations that reach the floor for no more than one year. My proposal is modeled on the power of the British House of Lords to block most bills passed by the House of Commons from becoming law for a maximum of one year. ${ }^{6}$ I argue that such a system would strike a better balance between a majority's right to rule and the minority's right to be heard. A suspensory veto under Rule XXII would also return the Senate to its traditional practice, which let a determined majority get its way except at the end of a Congress when claims of undue haste were more legitimate. ${ }^{7}$

\footnotetext{
5 This Essay assumes that Rule XXII is constitutional, or at least that no court would invalidate a long-standing Senate rule. See U.S. ConST. art. I, § 5, cl. 2 ("Each House may determine the Rules of its Proceedings . ..."); Fisk \& Chemerinsky, supra note 3, at 243 ("History strongly suggests that allowing Congress to implement a supermajority voting rule is constitutionally acceptable."); Gerhardt, supra note 3 , at 449 ("[T] he filibuster is best understood as a classic example of a nonreviewable, legislative constitutional judgment.").

${ }^{6}$ See Parliament Act, 1949, 12, 13 \& 14 Geo. 6, c. 103, § 1 (U.K.) (stating that the House of Commons may enact a bill over the objection of the House of Lords by passing the bill in two consecutive sessions); Parliament Act, 1911, 1 \& 2 Geo. 5, c. 13, § 1(1) (U.K.) (providing that money bills may be enacted by the House of Commons over the objections of the Lords after a one-month delay). Part II.B explains how this rule emerged and why that history is pertinent for the Senate cloture debate.

${ }^{7}$ See BINDER \& SMITH, supra note 3, at 6 ("Taking advantage of the constitutionally mandated adjournment of Congress on March 4 of the odd-numbered years [prior to the Twentieth Amendment], senators perfected the art of exploiting the rules at the end of the session to block action on measures they opposed ...."); Fisk \& Chemerinsky, supra note 3, at 195 ("The early filibusters were largely unsuccessful in blocking legislation; almost every filibustered measure before 1880 was eventually passed.”). A majority with intense preferences almost always prevailed, because it could threaten to end obstruction through a ruling by the presiding officer, which is now called the "nuclear" or "constitutional" option. See WAWRO \& SCHICKLER, supra note $\dagger$, at 11 (arguing "that the mutability of the Senate's rules was an important constraint on obstructive behavior in the 19th century"); Martin B. Gold \& Dimple Gupta, The Constitutional Option to Change Senate Rules and Procedures: A Majoritarian Means to Overcome the Filibuster, 28 HARV. J.L. \& PUB. POL'y 205, 260-61 (2004) (explaining how a majority could invoke cloture by tabling a ruling from the presiding officer that any further debate on a pending motion is out of order); infra text accompanying notes $31-35$.
}

This Essay takes no position on whether a majority can amend the cloture rule or whether Rule XXII's statement that a two-thirds vote is required is controlling. Compare Gerhardt, supra note 3, at 445 n.* (stating that the nuclear option "is illegal and constitutes an unfortunate breach of the Senate's heretofore unbroken practice of amending its rules in strict accordance with its rules"), with John C. Roberts, Majority Voting in Congress: Further Notes on the Constitutionality of the Senate Cloture Rule, 20 J.L. \& POL. 505, 507 (2004) ("[T]he Cloture Rule, and therefore the filibuster rule itself, are in fact subject to the will of a simple majority of the Senate at any time. I argue that this is true both as a matter of Senate practice and of constitutional principle."). I also do not address whether, if a two-thirds vote is required, it is an unlawful entrenchment of cloture. Compare Fisk \& Chemerinsky, supra note 3, at 185 (stating that Rule XXII is unconstitutional because it "impermissibly entrenches the views of today's Senate by dictating rules for future Congresses"), with Gerhardt, supra note 3, at 448 ("Article I contains no explicit or implicit antientrenchment principle that would preclude the Senate from adopting procedural rules that carry over from one session to the next and may only be altered with supermajority approval."). For a thoughtful discussion on the automatic continuation of Senate rules from one Congress to the next, see Aaron-Andrew P. Bruhl, Burying the "Continuing Body" Theory of the Senate, 95 IOWA. L. REV. 1401 (2010). 
The main reason why cloture should be reformed is that unlimited Senate debate is now little more than a legal fiction. ${ }^{8}$ Under the modern twotrack legislative calendar that allows the Senate to proceed to other business while a bill or nomination is being filibustered, a vote against cloture does not lead to extended floor debate - it leads to no floor debate. ${ }^{9}$ The Majority Leader almost always pulls the disputed bill (or does not bring it forward in the first place) and turns to something else. ${ }^{10}$ Since it is impractical to end the two-track system because of senators' aversion to the unpleasant schedule that is created by round-the-clock speeches, there is no persuasive deliberative basis for the current cloture rule. ${ }^{11}$ On the other hand, solicitude for minority rights and a desire to stop laws from being rushed through without appropriate scrutiny suggest that permitting the majority to end a debate at any time would be wrong. Ironically, the House of Lords, which is the least studied or respected legislative body in any major democracy, ${ }^{12}$ offers the best way of thinking about the filibuster. The Lords' suspensory veto is the product of nearly a century of debate in Britain about the role

8 See Fisk \& Chemerinsky, supra note 3, at 184 ("The modern filibuster, by contrast, has little to do with deliberation and even less to do with debate. The modern filibuster is simply a minority veto, and a powerful one at that."); $c f$. BINDER \& SMITH, supra note 3, at 1 (“According to conventional wisdom, the right of unrestricted debate in the Senate helps moderate extreme legislation, blocks passage of measures opposed by a popular majority, and is inseparable from the origins and traditions of the Senate. Such claims are, in fact, mostly myth: there is scarce theoretical or empirical support for much of the received wisdom about the Senate filibuster.").

9 See Fisk \& Chemerinsky, supra note 3, at 201 ("In response to repeated civil rights filibusters, Majority Leader Mike Mansfield developed a system whereby the Senate would spend the morning on the filibustered legislation and the afternoon on other business."); Gold \& Gupta, supra note 7, at 25253 ("By 1975, the Senate had implemented a 'two-track system' for considering legislation, which allowed the Senate to "continue to work on all other legislation on one "track," while a filibuster against a particular piece of legislation [wa]s theoretically in progress on the other "track."," (alteration in original) (quoting 94 CONG. REC. 928, 928 (1975) (statement of Sen. Cranston)).

10 See WAWRO \& SCHICKLER, supra note †, at 259-60 ("If the supporting coalition behind a piece of major legislation is not large enough to invoke cloture, the legislation is not likely even to make it to the floor."); Fisk \& Chemerinsky, supra note 3, at 203 ("A credible threat that forty-one senators will refuse to vote for cloture on a bill is enough to keep that bill off the floor.").

11 See BINDER \& SMITH, supra note 3, at 216 ("Party leaders-trying to cater to their members' frequent requests for a more predictable and family-friendly (let alone fundraising friendly) schedule-are unlikely to want to enforce round-the-clock filibusters at the expense of creating a logjam of important legislative business."); see also WAWRO \& SCHICKLER, supra note $\dagger$, at 262 ("[I]t is the choice of a majority not to engage obstructing senators in a war of attrition.”).

12 See, e.g., ThE Federalist No. 63, at 430 (James Madison) (Jacob E. Cooke ed., 1961) (calling the House of Lords a "hereditary assembly of opulent nobles"); see also WALTER BAGEHOT, THE ENGLISH CONSTITUTION 95 (Cosimo Classics photo. reprint 2007) (1873) (stating that the House of Peers was inferior because "[ $\mathrm{t}$ ]he qualities which fit a man for marked eminence, in a deliberative assembly, are not hereditary, and are not coupled with great estates”); JENKINS, supra note $\ddagger$, at 55 (quoting Winston Churchill's view that the Lords was a "one-sided, hereditary, unprized, unrepresentative, irresponsible absentee"). Most of the hereditary peers were finally removed from the House of Lords in 1999, see House of Lords Act, 1999, c. 34 (U.K.), and now most of its members are lifetime appointees, see Life Peerages Act, 1958, 6 \& 7 Eliz. 2, c. 21 (U.K.). Indeed, I cannot find any law review articles that take a close look at the legislative procedures of the House of Lords. 
that countermajoritarian practices should play within a democratic legislature, and thus it is analogous to the ongoing debate over the proper scope of minority rights within the Senate.

Convincing people that the filibuster should be turned into a suspensory veto is one thing; convincing the Senate to adopt this idea is something else. Public pressure forced the adoption of the first cloture rule in $1917,{ }^{13}$ but that may not be enough this time. In some cases, the Senate responds only to institutional pressure. For instance, when reformers sought to end the power of one-third of the Senate to control Native American policy by rejecting tribal treaties, the House of Representatives refused to appropriate funds for those treaties and forced the Senate to agree that the tribes should always be regulated by ordinary legislation. ${ }^{14}$ When progressives could not get a Senate supermajority to pass the proposed Seventeenth Amendment, which provided for the direct election of senators, almost two-thirds of state legislatures petitioned for a constitutional convention, and the Senate gave way. ${ }^{15}$ And when internationalists in the 1940s wanted to make sure that a Senate minority could not repeat the mistake of rejecting the League of Nations, the House passed a constitutional amendment abolishing the treaty ratification process, and the Senate accepted the idea that a congressionalexecutive agreement passed just like a bill could be the legal equivalent of a treaty. ${ }^{16}$ Obtaining cloture reform may require this kind of robust action from other elected officials.

Part I traces the evolution of the filibuster and argues that the current version should not be retained because it is inconsistent with the majoritarian tradition of the Senate. Part II argues for suspensory cloture and examines how concerns about the lack of democracy within Parliament led to the creation of a similar rule for the House of Lords. Part III explores past cases where the Senate was strong-armed into giving up its prerogatives and provides some suggestions on how that could be done to reform the filibuster.

\footnotetext{
13 See Robert Mann, The Walls of Jericho: Lyndon JohnSOn, Hubert HumPHREy, Richard Russell, AND the Struggle for Civil Rights 79 (1996) (stating that President Woodrow Wilson "shamed senators into enacting a cloture rule" after a filibuster blocked a bill to arm merchant ships); Gold \& Gupta, supra note 7, at 217-19 (describing public outrage at this end-of-session filibuster by eleven isolationist Senators).

${ }^{14}$ See Act of Mar. 3, 1871, ch. 120, 16 Stat. 544, 566 (codified at 25 U.S.C. $\$ 71$ (2006)) (abolishing the tribal treaty system); Antoine v. Washington, 420 U.S. 194, 201-02 (1975) (describing this struggle in the 1860 s and 1870 s); see generally U.S. CONST. art. II, § 2, cl. 2 (stating that "two thirds of the Senators present" must concur to ratify a treaty).

15 See Gerard N. Magliocca, State Calls for an Article Five Convention: Mobilization and Interpretation, 2009 CARDOZO L. REV. DE NOVO 74, 79-81, http://www.cardozolawreview.com/content/denovo/ Magliocca_2009_74.pdf (describing this showdown over the Seventeenth Amendment).

16 See Bruce AcKerman \& DAVId Golove, Is NAFTA Constitutional? 89-96 (1995) (describing how the Senate relinquished its treaty monopoly during the mid-1940s); see also JOHN MiLTON COOPER, JR., WOODROW WILSON 506-59 (2009) (recounting the Senate debate over the Treaty of Versailles).
} 


\section{THE History OF UNLIMITED DEBATE}

This Part looks at the gradual shift of the Senate's norms with respect to floor debate. Given the current premise that it takes sixty senators to get anything significant done, it be may startling to learn that for most of its history the Senate functioned on the assumption that a simple majority was sufficient unless an issue was taken up in the closing days of a Congress. ${ }^{17}$ During that era, which lasted until the 1970s, unlimited debate was mainly a procedural device that protected free speech, improved the quality of deliberation, and revealed the intensity of preferences in the Senate. ${ }^{18}$ But today cloture is mostly a substantive supermajority voting rule that does not accomplish these traditional goals and is difficult to justify on other grounds.

\section{A. Folkways in the Traditional Senate}

The best place to start is by asking how the Senate got anything done before 1917, when unanimous consent was necessary to cut off debate and move to a final vote. ${ }^{19}$ Common sense says that senators could not have

17 See WAWRO \& SCHICKLER, supra note $\dagger$, at 28 ("When an issue was salient to both the majority and the minority, the pre-cloture Senate was essentially majoritarian, with the sole caveat being that filibusters in the final few days of a congress posed by a genuine threat to legislation."); see also BINDER \& SMITH, supra note 3, at 5 ("It was widely assumed in these first decades that measures would be brought to a vote for final consideration and that a simple majority would be sufficient for ending debate on even the most controversial legislative business."). After all, plenty of legislation passed the Senate with less than two-thirds support prior to 1975, when cloture required a two-thirds vote. See MANN, supra note 13, at 519-20 (listing the versions of Rule XXII from 1917 to 1975). And bills or nominations did not require unanimity before 1917 , when there was no cloture rule at all. Id.

18 See WAWRO \& SCHICKLER, supra note $\dagger$, at 36 ("[F]ilibusters (and efforts to fight obstruction) can signal the intensity of constituent support or opposition to a position, which should prove to be electorally useful information for all senators."). Needless to say, not all filibusters are enlightening. See FRANKLIN L. BuRdetTE, FILIBUSTERING IN THE SENATE 3-4 (1940) (describing Senator Huey Long's 1935 filibuster in which he read recipes for "potlikker" and Roquefort salad dressing).

I am not going to spend any time discussing the free speech or quality-of-discussion issues, as I think it is rather obvious that these values are protected or enhanced by unlimited debate on the floor.

19 See, e.g., Robert A. Caro, Master of the Senate: The Years of Lyndon Johnson 92 (2002) ("For many years after 1806 - for 111 years, to be precise - the only way a senator could be made to stop talking so that a vote could be taken on a proposed measure was if there was unanimous consent that he do so, an obvious impossibility."). From 1789 until 1806, the Senate did have a rule providing that a majority could call the previous question. See Gold \& Gupta, supra note 7, at 213 ("The previous question being moved and seconded, the question for the chair shall be: 'Shall the main question now be put?' and if the nays prevail, the main question shall not then be put." (quoting RULES Adopted by the First Senate of the United States Rule IX, 1 Annals of Cong. 20-21 (Joseph Gales ed., 1789)); id. at 215-16 (quoting Vice President Aaron Burr's rationale recommending "the abolition of that respecting the previous question, which he said had in the four years been only once taken, and that upon an amendment. This was proof that it could not be necessary, and all its purposes were certainly much better answered by the question of indefinite postponement." (quoting 1 MEMOIRS OF JOHN QUINCY ADAMS 365 (Charles Francis Adams ed., 1874)). Scholars disagree about the purpose of the previous question rule in part because the Senate's early records are incomplete. See Fisk \& Chemerinsky, supra note 3, at 188 ("Both friends and foes of filibusters in the Senate have attempted to find in the previous question motion a pedigree for their views on whether the early Senate allowed 
viewed unanimous consent as the equivalent of a voting rule on the merits. In those days, the Senate was smaller and not very busy. This allowed its members to foster cooperative norms and discourage dilatory tactics. ${ }^{20}$ Moreover, Senate precedent held that the rulings of the presiding officer, backed by a majority of the chamber, could be used to limit obstruction. ${ }^{21}$ As a result, there were almost no successful filibusters before the $1880 \mathrm{~s}^{22}$

One reason the Senate functioned well without a cloture rule for so long is because its small size allowed that body to reach an informal understanding that a majority should prevail once everyone had a chance to express his opinion. There is nothing novel about the suggestion that a small community engaged in repeated interactions is likely to settle on a set of mutually beneficial norms. ${ }^{23}$ Not only is there an advantage to reciprocity under those conditions, but there are also high costs to disruptive behavior because of its visibility and the ability of a tight-knit group to stick together and shun those who do not conform to the prevailing institutional culture. ${ }^{24}$ The growth in the Senate's ranks during the nineteenth and twentieth centuries undermined that informal system, but it is hard to say that this increase did much to change the filibuster. ${ }^{25}$

unlimited debate, but the historical record resists simple characterization. It is unclear whether the previous question, in the form then practiced, served as a device to bring a measure to a vote, or whether it served to defer discussion of sensitive or embarrassing questions. The one issue on which both sides agree, however, is that the previous question motion was seldom used before the Senate abolished it in the 1806." (footnotes omitted)); cf. BURDETTE, supra note 18, at 16 ("Debates in Congress were often scantily reported, and in the Senate they were secret till 1794.").

20 Fisk \& Chemerinsky, supra note 3, at 184 ("[T] he smaller size, lighter workload, and more collegial culture of the pre-1950 Senate imposed significant limits on the ability of the minority to use the filibuster to thwart the majority."); see also BURDETTE, supra note 18, at 14 ("Tactics patently obstructive, however, were characteristic of the House long before they became common in the Senate. That fact may be ascribed to the small membership of the early Senate and to the dignity and polished politeness with which its proceedings were conducted ....").

${ }^{21}$ See, e.g., WAWRO \& SCHICKLER, supra note $\dagger$, at 27-28 ("Senators understood that a determined majority, particularly when supported by a sympathetic presiding officer, could implement new precedents that neutralized minority obstruction.”). To take a modern example, in 1969 Vice President Hubert Humphrey issued a ruling that the Senate could, at the start of a new Congress, invoke cloture by a simple majority on a proposed change to Rule XXII itself. See Gold \& Gupta, supra note 7, at 251. A majority of the Senate (53-45) rejected this ruling, see id. at 252, but the point is that only a majority was necessary to uphold the ruling of the chair.

22 See BuRDETTE, supra note 18, at 35-39 (discussing an unsuccessful 1879 filibuster and concluding that "on the whole, it had been a device remarkably unsuccessful; almost every obstructed measure was eventually passed despite filibustering opposition").

${ }^{23}$ See generally Robert C. Ellickson, Order Without Law: How Neighbors Settle DISPUTES (1991) (exploring the development of self-enforcing norms and informal rules).

${ }^{24}$ See WAWRO \& SCHICKLER, supra note $\dagger$, at 50-54 (discussing some examples of norm enforcement against troublesome senators, though noting that the proof and effectiveness of these informal sanctions is unclear).

25 See 27 CONG. REC. 45-46 (1894) (statement of Sen. Vest) (criticizing unlimited debate given the increased size of the Senate). The Senate is almost the same size as it was in 1912 (only Hawaii and Alaska were added as states in the 1950s), yet the practice of unlimited debate, as the text explains, 
Another explanation for the lack of a cloture rule was that the threat of obstruction through unlimited debate was hollow for much of the Senate's history because senators did not have much to do. In 1827, for example, a journalist noted that the Senate usually met from noon until three and did not meet five days a week. ${ }^{26}$ Without much to occupy its time on the floor, a majority could easily afford to wait out any attempt to bring the Senate's business to a halt, which in turn made it unlikely that anybody would try. ${ }^{27}$ The exception was at the end of a Congress, when dilatory tactics could not be brushed aside by patience, because the time available for debate was scarce. ${ }^{28}$ In 1917, the Senate decided that it needed a cloture rule to stop these last-minute filibusters by allowing two-thirds of the Senate to end debate, which was an effort to balance the desire to prevent bills from being rushed through before an adjournment with the view that a handful of senators should not be able to veto legislation. ${ }^{29}$ The rest of the time, though, the slack in the calendar gave the majority broad latitude to govern. ${ }^{30}$

changed dramatically during that time. It may be, though, that the increasing size of the Senate explains the breakdown of norms against end-of-session filibusters in the late nineteenth century.

${ }^{26}$ See BINDER \& SMITH, supra note 3, at 40 (citing journalist Ben Perley Poore's observation of the Senate's "rather leisurely schedule").

${ }^{27}$ See id. at 42 ("Hardly in a rush to conclude business on a host of pressing issues, Senate majorities would have had the liberty of sitting out any set of obstructive senators, knowing that they would not be putting a heavy agenda at risk."); BURDETTE, supra note 18, at 34 ("Earlier filibusters had been extended, but for the most part they were virtually uncontested; habitually the majority had abjectly even if impatiently waited for release by the minority.").

${ }^{28}$ See WAWRO \& SCHICKLER, supra note $\dagger$, at 121 (estimating that about a third of the filibusters or dilatory tactics employed prior to the establishment of the cloture rule in 1917 occurred in the final thirty days of a Congress); Fisk \& Chemerinsky, supra note 3, at 202 n.114 ("Many filibusters occurred during the short sessions that ended at noon on the March 4th after an election."); see also BURDETTE, supra note 18, at 213 ("It has become axiomatic that filibusters can be conducted with greatest effectiveness for a given quota of exertion near the time for final adjournment, and for that reason they are most frequent at the ends of sessions."). There is an analogy here to the President's "pocket veto" power, which allows him to kill a bill passed at the end of a Congress by refusing to act on it. U.S. ConST. art. I, $\S 7$, cl. 2 ("If any Bill shall not be returned by the President within ten Days (Sundays excepted) after it shall have been presented to him, the Same shall be a Law, in like Manner as if he had signed it, unless the Congress by their Adjournment prevent its Return, in which Case it shall not be a Law."). In effect, Article I gives the President a ten-day suspensory veto.

29 See WAWRo \& SCHICKLER, supra note $\dagger$, at 125 (stating that as norms of restraint "began to break down in the late-19th century, even large majorities were by no means assured of success in the waning days of a Congress. This breakdown of informal restraints, in turn, motivated senators to move toward a formal cloture rule that reduced the uncertainty posed by late-congress filibusters by small minorities"); cf. Fisk \& Chemerinsky, supra note 3, at 197 (quoting President Wilson's denunciation of an end-of-session filibuster that led to the creation of the cloture rule, in which he observed that "[m]ore than 500 of the 531 members of the two houses were ready and anxious to act; the House of Representatives had acted, by an overwhelming majority; but the Senate was unable to act because a little group of eleven senators had determined that it should not." (quoting 41 THE PAPERS OF WOODROW WILSON 319-20 (Arthur S. Link ed., 1983)).

30 The debate on the 1890 "Force Bill," which would have strengthened federal protection of voting rights in the South, is frequently cited as an example of a successful filibuster. See BURDETTE, supra note 18 , at $52-57$. In that instance, though, a majority decided to set aside the bill after being per- 
Permitting unlimited debate was also not a problem because a majority could credibly threaten to create a cloture rule if a minority violated the Senate's custom by refusing to allow a bill to move to a final vote. ${ }^{31}$ If a member made a point of order stating that debate on a pending matter should end or that a particular parliamentary tactic was inappropriate, the presiding officer could sustain the motion and have his ruling upheld by a simple majority. ${ }^{32}$ That ruling would then be a binding precedent under long-standing Senate practice. While there was no time limit on a debate of the presiding officer's ruling, a filibuster on that action could be preempted by a motion to table, as that motion was not debatable. ${ }^{33}$ This sort of procedure was invoked many times so that senators bent on obstruction knew that they could not go too far without creating a backlash. ${ }^{34}$ Oddly enough, the establishment of Rule XXII probably made it harder to stop a filibuster by removing the ambiguity surrounding unlimited debate. That is why the prospect of ending the sixty-vote cloture requirement through a ruling by the presiding officer is now often referred to as the "nuclear" option, because many view the idea as contrary to the rules of the Senate. ${ }^{35}$

suaded - following a lengthy discussion - that it should not pass. See id. at 57 (stating that the motion to pull the bill from the floor passed 35-34); see also WAWRO \& SCHICKLER, supra note $\dagger$, at 4 (" $[T]$ he record suggests that Republicans lacked a floor majority for both cloture and the Elections Bill itself.").

31 See Gold \& Gupta, supra note 7, at 220-69 (undertaking an exhaustive examination of cases where the threat of a majority to end unlimited debate led to rule changes endorsed by a supermajority of the Senate).

32 See WAWRO \& SCHICKLER, supra note $\dagger$, at 68 (“[T] here are examples in which the chair made a controversial ruling, and it was then appealed and sustained by a majority vote without a filibuster of the appeal."); $i d$. ("We have found no examples of appeals of rulings by a chair being successfully filibustered in the 19th century ...."). For controversial rulings, the presiding officer was normally the Vice President. U.S. CONST. art I, § 3, cl. 4 ("The Vice President of the United States shall be President of the Senate, but shall have no vote, unless they be equally divided.").

33 See WAWRO \& SCHICKLER, supra note $\dagger$, at 33 ("A motion to table the appeal is not debatable, and tabling an appeal requires only a simple majority vote. Once an appeal has been tabled, the ruling is considered to be sustained and to constitute a precedent, which is just as binding as a standing rule. Avoiding additional obstruction on the appeal of a chair's ruling would simply require that the chair first recognize an individual friendly to the ruling who will make the motion to table." (footnotes omitted)).

${ }^{34}$ See id. at 70 (providing a set of examples where procedural rulings established precedents that limited obstruction); id. at 68-69 ("[C]hairs issued controversial new rulings in the 19th century, and it does not appear that the minority used obstruction to block such rulings from taking effect."); cf. Gold \& Gupta, supra note 7, at 260 ("Each time the Senate rules have been amended, the body has followed the rules-change procedure set forth in the rules themselves. Yet, on at least four occasions those changes were forced by attempts to use the constitutional option," which refers to obtaining a favorable ruling from the presiding officer.).

35 See WAWRO \& SCHICKLER, supra note †, at 273 ("In today's Senate, implementing the nuclear option appears to run afoul of the explicit rules of the Senate in a manner that did not hold prior to 1917. It is critical to emphasize that a floor majority can still choose to go nuclear, but doing so poses heightened political risks since it can effectively be portrayed as violating a long-standing explicit rule of the Senate."); see supra note 7 (noting the divided opinion on the nuclear option). 
Finally, the Senate could indulge unlimited debate because filibusters were physically taxing. ${ }^{36}$ Only a zealous minority would have the strength to hold the floor for days or weeks. The physically taxing nature of filibusters discouraged obstruction and provided valuable information about how strongly each side felt about the issue being discussed..$^{37}$ One criticism of "yes-or-no" voting rules is that they do not measure preference intensity and can provide a false impression of majority opinion. ${ }^{38}$ The decision to conduct a filibuster, by contrast, sent a signal that some senators were fiercely opposed to a pending bill, which might cause the majority to rethink its views. ${ }^{39}$ Likewise, a majority's choice to keep a challenged bill on the floor and forsake all other legislative action until it passed showed its commitment to an issue and might cause the minority to relent. ${ }^{40}$ Thus, there was a strong argument that the lack of a cloture rule (or the lack of one that a majority could easily invoke) improved the deliberative process.

Most scholars agree that the adoption of Rule XXII did little to change the Senate's culture, but an exception emerged to the premise that the majority should prevail on the floor for civil rights legislation. ${ }^{41}$ Bills attacking

\footnotetext{
${ }^{36}$ Engaging in unlimited debate is also politically taxing, as it is a highly visible act that can backfire if there are relevant constituencies in favor of the bill under discussion. $C f$. Fisk \& Chemerinsky, supra note 3, at 206 ("Now, of course, C-SPAN coverage of floor proceedings would make it even easier for the public to know about filibusters, which would substantially limit their use. In an era of public concern over 'gridlock' in Washington, most senators would not want their constituents to witness an old-fashioned filibuster.").

37 See WAWRO \& SCHICKLER, supra note $\dagger$, at 18 ("The key question in pre-cloture filibuster battles was which side had the greater resolve to bear such costs in order to secure its favored outcome. We argue that this institutional context fostered confrontations that were akin to game-theoretic models of 'wars of attrition' and that electorally relevant information conveyed through filibuster battles helps to explain why a legislature would choose to allow minorities to obstruct business in the first place.").

38 See, e.g., Kevin A. Kordana, Political Parties as Donative Intermediaries, 85 VA. L. REV. 1683, 1683-84 (1999) (discussing "one of the crucial problems of democracy: Voting does not take account of individual voters' intensity of preference").

39 See WaWro \& SCHICKLER, supra note $\dagger$, at 18 . The decision to filibuster at the end of a Congress is not indicative of intense minority opposition because the cost of obstruction is lower (e.g., if only four hours remain until adjournment, then someone just needs to give a four-hour speech to kill a bill). On the other hand, one might say that the fact that a bill is brought to the floor at such a late date indicates that it is a low priority for a Senate majority, and hence the bill should be defeated if an intense minority thinks it is a bad idea.

40 The best example was the filibuster of the Civil Rights Act of 1964, which lasted for three months until cloture was invoked. See MANN, supra note 13, at 406-28 (discussing this debate).

${ }^{41}$ See Fisk \& Chemerinsky, supra note 3, at 198-99 ("For nearly fifty years after its adoption, Rule XXII served a purpose more symbolic than real. Between 1917 and 1927, cloture was voted on only ten times and it was adopted only four times. Between 1931 and the enactment of the Civil Rights Act of 1964, cloture was seldom sought and only twice obtained. The reluctance to seek cloture and the difficulty of obtaining it resulted in large part from the battle over civil rights ...." (footnotes omitted)); see also MANN, supra note 13, at 79 ("An accumulation of interpretations and precedents in the years following 1917-declaring that the Senate could end debate on measures but not on motions or procedural questions - had left the cloture rule largely impotent and meaningless."). Filibusters still occurred in the waning days of a Congress, as they had before 1917.
} 
lynching, segregation, or the denial of voting rights to African-Americans were always filibustered and could not pass without a two-thirds vote. ${ }^{42}$ While the civil rights exception was a harbinger of cloture's change in emphasis from a procedural device into a substantive one, until the 1970s no other legislation faced this extraordinary hurdle. ${ }^{43}$ Southern senators who opposed federal civil rights wanted to avoid cloture reform, and so they refrained from filibustering anything else. ${ }^{44}$ At the same time, liberals who saw civil rights as the crucial issue felt that they should not legitimize filibusters and therefore never joined one. ${ }^{45}$ The enactment of the Civil Rights Act of 1964 and the Voting Rights Act of 1965 brought this era to an end and ushered in the conception of the filibuster that is the source of concern today. ${ }^{46}$

\section{B. The Two-Track System and Supermajority Rule}

Over the past four decades, the Senate abandoned the expectation that the majority should prevail and shifted toward supermajority rule. A major reason for that shift was an increase in legislative business. ${ }^{47}$ The growth of the welfare and administrative state makes floor-debate time much more precious and makes it far more costly for the Senate to be tied up by a fili-

42 See BINDER \& SMITH, supra note 3, at 136 ("[B]y the mid-twentieth century it is clear that civil rights measures as a class were the dominant subject of measures that can reasonably be claimed to have been killed by filibuster. And the connection between civil rights and the cloture rule was plain to everyone.").

43 See Roberts, supra note 7, at 521 ("Filibusters were not seen as a general threat to legislation during this period, and were not often used, except against civil rights legislation."). The procedural/substantive distinction in the text is not absolute, as the traditional filibuster had a substantive component with respect to blocking a bill at the end of a Congress. Likewise, a modern filibuster still can further some procedural values (e.g., revealing preference intensity) in the right circumstances. The point is that unlimited debate used to be mostly a deliberative tool, and it now operates mostly as a substantive voting rule.

44 See Fisk \& Chemerinsky, supra note 3, at 200 ("[T]he Southern Democrats monopolized filibustering as an anti-civil rights device."). Another argument is that conservatives dominated the committee system in this period and thus had no need to filibuster. See BINDER \& SMITH, supra note 3, at 89 ("The conservative coalition was generally satisfied to have little new legislation pass and, because it constituted a majority of the Senate during much of this period, did not have to resort to the filibuster to block liberal legislation. Only on civil rights measures, which were attractive to many Republicans, did southerners regularly have to resort to filibusters or threaten filibusters to kill undesirable legislation .....").

${ }^{45}$ See, e.g., Fisk \& Chemerinsky, supra note 3, at 200 ("[T]he debate about civil rights legislation became fused with the debate about filibusters and cloture: Conservatives defended them and liberals opposed them.").

46 See Bruce Ackerman \& Jennifer Nou, Canonizing the Civil Rights Revolution: The People and the Poll Tax, 103 Nw. U. L. REV. 63, 90-110 (2009) (describing the legislative history of the Voting Rights Act); see also Fisk \& Chemerinsky, supra note 3, at 199 ("The filibuster against the Civil Rights Act of 1964 was unequaled in length and notoriety; it tied up the Senate for seventy-four days.").

47 See Fisk \& Chemerinsky, supra note 3, at 186 ("[T] he filibuster is a more significant institutional problem in the Senate today. The huge increase in Congress' workload over the last forty years largely accounts for this."); see also BINDER \& SMITH, supra note 3, at 13 ("The expansion of the Senate's workload in recent decades has no doubt made it easier for senators to obstruct chamber business."). 
buster ${ }^{48}$ In effect, an entire Congress now faces the sort of acute time pressure that used to appear only in the last days of a Congress. Thus, a minority now has a stronger incentive to obstruct because it knows that resistance is likely to force the majority to fold or bargain. Moreover, the stigma that attached to voting against cloture during the civil rights era (for liberals on all issues and for conservatives on non-civil rights bills) vanished after 1965 , thus weakening the informal restraint on the use of unlimited debate. $^{49}$

To avoid perpetual gridlock, the Senate started using a two-track system that allowed the chamber to tackle other business (with unanimous consent) for part of the day while a filibuster was alive on another issue. ${ }^{50}$ The two-track system reduced the cost of filibusters for the minority - it did not need to hold the floor constantly as in the past - and for the majority, which could withstand opposition without being forced to relinquish other legislative priorities. In time, the two tracks existed only as a formal matter: whenever a credible filibuster threat was made, the contested matter was set aside entirely until the necessary votes for cloture were rounded up. ${ }^{51}$ There is no rule that mandates this practice; a majority can choose to keep a filibustered bill on the floor and force the minority to endure the hardships of endless debate. ${ }^{52}$ But this almost never happens today.

\footnotetext{
48 See BINDER \& SMITH, supra note 3, at 15 ("Senators seeking to block action on a particular measure know that increased time pressures will often work in their favor: the heavier the agenda, the less likely that party leaders will be able to afford the time to wait out filibustering senators."); WAWRO \& SCHICKLER, supra note $\dagger$, at 261 ("[F]ilibustering has become costless for bill opponents for the simple reason that the opportunity costs of waiting out a filibuster have become overwhelming when senators are confronted with extraordinarily tight scheduling constraints.").

49 See Fisk \& Chemerinsky, supra note 3, at 201 ("The fusion of filibusters and civil rights issues rapidly dissolved in the 1970s when liberals began to filibuster and conservatives began to vote for cloture."). It is also possible, though there is no evidence on this point, that lowering the cloture threshold from sixty-seven votes to sixty in 1975 made filibusters seem less extraordinary and more acceptable within the culture of the Senate.

50 See BINDER \& SMITH, supra note 3, at 15 (describing the two-track approach implemented as standard procedure by Majority Leader Mike Mansfield and his deputy, Senator Robert C. Byrd, in the 1970s); WAWRO \& SCHICKLER, supra note †, at 261 ("[T] he much-discussed multi-tracking system devised by Mike Mansfield and Robert Byrd in the early 1970s is more a symptom of this transformation to costless filibustering than its cause."). The Senate sometimes used a two-track process before the 1970 s, but it is used almost all the time now. See WAWRO \& SCHICKLER, supra note $\dagger$, at 262.

${ }^{51}$ See Fisk \& Chemerinsky, supra note 3, at 186 ("We then describe the transformation of the filibuster from the old form of extended debate to its modern incarnation as 'the stealth filibuster' - a covert procedural maneuver largely invisible to the public.").

${ }^{52}$ In theory, a filibuster can be defeated if the Senate is kept in continuous session for a long enough period of time because no Senator is allowed to give more than two speeches on the same topic during a legislative day. See U.S. Senate Comm. On Rules and Admin, Standing Rules of the Senate, S. Doc. No.110-9, at 14 (Rule XIX(1)(a)), available at http://rules.senate.gov/public/index.cfm? $\mathrm{p}=$ RuleXIX. Since a legislative day generally does not elapse until the Senate stands in recess, eventually all of the filibustering Senators would give their two speeches and not be able to gain recognition from the chair. In practice, though, keeping the Senate going for a full legislative day is impossible.
} 
Accordingly, the administration of Rule XXII is now sharply at odds with the purpose of unlimited debate. Just a credible threat to vote against cloture stifles the exchange of ideas by ensuring in most cases that a contested bill or nomination will not be debated on the floor. ${ }^{53}$ The modern filibuster does not enhance the quality of deliberation, protect the free speech of individual senators, or reveal preference intensity in the Senate. On the last point, since a minority only needs to say that it will refuse to vote for cloture, almost nothing is disclosed by that threat that is different from a vote on the merits. ${ }^{54}$ In effect, modern cloture practice operates as a gag rule.

The best objection to this characterization is that a refusal to vote for cloture actually leads to more debate off of the Senate floor, but this argument is not convincing. First, many matters held up by a filibuster threat probably just disappear and get no attention. Second, if additional discussion does occur as a result of Rule XXII, it usually takes place in the catacombs of the Capitol, out of the public eye. Secret talks are a necessary part of the legislative process, of course, but it is hard to argue that we have too much transparency and that a supermajority cloture rule is the best antidote. The rare case where a Senate deadlock leads to passionate conversations on television, around dinner tables, and in barbershops does not make up for the vast majority of cases where a filibuster stifles that dialogue.

Stripped of its procedural rationale, Rule XXII is reduced to a substantive minority veto. While the protection of minority rights is an important consideration, it is hard to see why a practice that is so inconsistent with the majoritarian tradition of the Senate should be retained. The burden of proof should be on the proponents of the new supermajority threshold. For example, why should a three-fifths limit apply in the Senate but not in the House of Representatives? Is there a good reason to require sixty senators

\footnotetext{
53 A separate, though related, problem is the use of "holds," whereby a senator privately informs the Majority Leader that unanimous consent will not be given on a pending matter unless certain concessions are made. See BINDER \& SMITH, supra note 3, at 11-12 (describing holds). The key problem with a hold is that by custom the Majority Leader does not reveal who has placed a hold on a particular item. Id. There is no justification for this secrecy, as it just lets senators escape accountability for their actions. For a discussion of how Lyndon Johnson pioneered the use of unanimous consent agreements to structure Senate debate when he was Majority Leader, see CARO, supra note 19, at 572-77.

54 See WAWRO \& SCHICKLER, supra note $\dagger$, at 260 ("The contemporary context of lawmaking in the Senate has essentially eliminated the informational benefits that used to accrue from these kinds of battles. The essential component that is now missing is that filibustering is virtually costless for bill opponents. With costless filibustering, undertaking obstruction no longer signals that a proposed policy is particularly harmful to its foes.").

In fairness, there are situations in which the minority expresses a weak preference by voting for cloture but against a pending matter on the merits. That could be because a norm against filibustering is still strong, or because the issue has low political salience and thus constituents will not treat a vote for cloture as the equivalent of a final vote.
} 
to support ordinary legislation or nominations? ${ }^{55}$ These questions need answers because minority rights in the Senate can be protected by something other than an absolute veto. Nevertheless, the minority party in the Senate and the senators in the majority who straddle the sixtieth-vote line benefit from the current approach to cloture, which helps explain why we still have Rule XXII.

One obvious cure would be for the majority to insist that all those in the minority be forced to hold the floor if they refuse to vote for cloture, but that is a bluff that can be called easily. Enforcing round-the-clock debate would clearly make filibusters more costly for obstructionists because they would have to hold the floor constantly, but this kind of war of attrition would also be costly for the majority. ${ }^{56}$ Even the most fervent senators are not eager to sleep on cots in their offices, answer quorum calls in the dead of night, or have their other legislative and political priorities held hostage by a chaotic schedule. Furthermore, having full-fledged filibusters would force many desirable bills off the floor and block their passage. ${ }^{57}$ The twotrack system, after all, was instituted because these repeated stalemates were considered harmful. And since the Senate has steadfastly refused to abandon this procedure for nearly forty years despite calls to make the minority conduct a "real filibuster" on one issue or another, the prospect of that actually happening on a regular basis seems remote.

In sum, the current practice of unlimited debate is inconsistent with the majoritarian premise that held sway in the Senate from 1789 until the 1970s. The procedural benefits of Rule XXII are all but gone given how the Senate now handles most cloture petitions, and there is no sound substantive basis for having a supermajority rule in just one house of Congress. Consequently, the analysis turns to how the filibuster should be reformed.

\section{A SUSPENSORY VETO AND THE HOUSE OF LORDS}

This Part argues that the cloture threshold should be changed into a temporary veto that a Senate majority can override after one year. ${ }^{58}$ Such a

\footnotetext{
55 Setting aside the Constitution's command that a Senate supermajority is necessary, for example, to ratify a constitutional amendment, one could make the case that for highly significant legislation there should be a norm that a narrow majority cannot act. Rule XXII, however, is being applied more widely, and besides, nobody is suggesting that the rules in the House of Representatives should be changed to conform to that norm.

56 See WAWRO \& SCHICKLER, supra note $\dagger$, at 263 ("[T] have become costless for the minority because the costs to the majority of engaging in wars of attrition have become prohibitively high."). There is no doubt that in some instances the minority would relent rather than conduct a formal filibuster if they were forced to do so, but the filibusters that did occur would be incredibly time-consuming and destructive.

57 This is especially true because many statutes have a definite expiration date (e.g., ones with sunset provisions) and therefore would lapse if the minority used the filibuster strategically.

${ }^{58}$ This kind of idea is certainly not original though the rationale offered here is new. See BURDETTE, supra note 18, at 240 ("[I]t would seem salutary to adopt a system of majority cloture appli-
} 
reform would dilute the minority's power to resist but retain the benefits of extended debate by encouraging dissenters to discuss contested issues on the floor and by letting them block items raised at the last minute. The inspiration for a suspensory cloture rule is the United Kingdom's House of Lords, which can delay but not defeat most bills passed by the elected House of Commons. ${ }^{59}$ Drawing an analogy between the Senate and the House of Lords is helpful not because they are the upper houses of their respective legislatures but because the current authority of the Lords evolved only after a prolonged struggle establishing that a substantive (rather than procedural) minority veto could not be squared with a democratic parliament. ${ }^{60}$ Rule XXII presents a similar problem and can be addressed with the same remedy.

\section{A. A Compromise Proposal}

Given the flaws in the current filibuster procedure, the simplest reform would be to let the Senate majority cut off debate whenever it wants. But this suggestion is unsound. There are good reasons for having lengthy floor consideration on some issues if a debate actually occurs - senators might learn something or be persuaded to change their minds. Similarly, there are valid substantive concerns about a runaway majority moving bills through late in a Congress without giving the minority or the public a chance to respond. The fact that extraordinary time pressure makes it easier to filibuster does not diminish the argument that there is a stronger justification for obstruction under those circumstances. Finally, the Senate can still use a mechanism to register preference intensity as cloture debates did before the two-track system took over. ${ }^{61}$

Giving forty-one senators the power to delay nominations or bills for only a limited period of time would address many of these issues by return-

cable upon a particular measure after unlimited debate for a specified minimum number of days. Such an alteration would not end obstruction. It would, however, make action by the Senate less difficult and more responsive to the will of a majority.").

59 A Parliament lasts for a maximum of five years unless both chambers vote to extend its term, which has not happened since World War II. See Parliament Act, 1911, 1 \& 2 Geo. 5, c. 13, § 7 (U.K.) (reducing the length of a Parliament from seven years to five); $i d$. $\$ 2$ (noting that a bill to extend a term of Parliament is exempt from the terms of the Act and thus requires the Lords' assent).

${ }^{60}$ To avoid confusion, there is no equivalent to the filibuster in the House of Lords. The comparison this Essay makes is at a higher level of generality between the Lords and the House of Commons, whereas in the Senate the relevant fight is between a majoritarian rule and a supermajority cloture rule.

${ }^{61}$ Admittedly, one could say that senators have better ways of learning about voter preferences (such as polls), but a cost-effective method of revealing that information in the chamber would still be helpful. In this respect, I think it would not be a good idea to reform cloture by forcing opponents to produce forty-one votes in order to continue debate whenever the majority makes such a demand (e.g., at $3 \mathrm{AM}$ on Christmas Eve). That would make it too difficult to mount a filibuster and be tantamount to majority cloture. 
ing cloture to its procedural roots. ${ }^{62}$ First, a minority that knows it cannot block a pending matter without convincing the majority to reverse course would have a strong incentive to take the floor and make its case. This would enhance the quality of debate in the Senate on many issues and make the dissidents accountable in a way that they are not under current filibuster practice, where they do not need to say anything. ${ }^{63}$ Second, giving the minority the right to impose a "cooling-off" period would keep the majority from acting recklessly and would let voters express their views in an election before a bill introduced at the end of a Congress could be enacted. ${ }^{64}$ Third, suspensory cloture would give the Senate a way to sort its internal preferences. If the majority failed to bring up a measure until a few months before the election, then that would show that its preference is rather weak because a filibuster could kill the proposal until the next Congress. ${ }^{65}$ At the same time, the minority would be making a significant statement if it fought to the bitter end on a timely matter despite knowing that the effort would be futile. ${ }^{66}$

One problem with having a time limit on a refusal to vote for cloture is that the limit must recognize that the Senate needs to pass legislation within a given Congress. Suppose that a bill comes to the floor with just six

\footnotetext{
${ }^{62}$ An alternative suggestion involves adopting a sliding scale that would let a majority end debate after a certain period of time but give, for example, fifty-five senators the power to impose cloture sooner. See BINDER \& SMITH, supra note 3, at 211 (describing this proposal). This is a fine idea too, but this Essay focuses on why setting a time limit is the right approach and not on how much time there should be.

The clock on any temporary veto should begin to run when a matter goes through the regular procedures and reaches the floor (whether by committee vote or by an amendment to pending legislation). A conference report reconciling the views of both houses should not be considered a separate bill subject to an independent delay, but if it is, then the duration of the veto should be reduced accordingly. On the other hand, at some point a substantive amendment to a pending bill should be deemed as restarting the clock, otherwise the majority could simply run out the one-year limit with "dummy" bills and then amend that legislation as if by majority cloture. One way to deal with this problem might be to say that any nongermane amendment restarts the cloture clock.

63 The minority could still force the majority to withdraw a measure by bringing all Senate business to a halt until its demand was met, but that is unlikely to occur. Such a threat would have to be carried out for a long time to be credible, and only a very intense opposition could manage that. In effect, turning cloture into a suspensory veto switches the burden of proof on this question from the majority to the minority. Holding the Senate hostage will also probably be a less effective strategy than using morning business (i.e., the time set aside for senators to discuss anything) to challenge a proposal in the hope that reason and a change in the political climate might cause the majority to reconsider.

${ }^{64}$ For an example of a hasty legislature, see Gerard N. Magliocca, Huey P. Long and the Guarantee Clause, 83 TUL. L. REV. 1, 13-14 (2008) (explaining that the Louisiana Legislature in the mid-1930s allowed a majority to suspend the rules and often passed legislation after only a few minutes of debate).

65 This would not always be true, as there are some bills that are brought forward late in a Congress because of a sudden crisis. Of course, there is also a strong argument that those kinds of measures should be given more careful consideration or should be discussed in an election campaign.

66 The evidence from the House of Lords after the creation of a suspensory veto in 1911 suggests that the power would not be used routinely. See JENKINS, supra note $\ddagger$, at 272-77 (noting that from 1911 to 1947 the Lords only rejected three bills passed by the House of Commons).
} 
months remaining in a Congress and is filibustered. Such a bill could not become law unless the Senate passed it again the next year, which would permit another round of delay depending on the result of the intervening election. In other words, a suspensory veto could be twice as long as the proposed rule contemplates. Perhaps this is the best approach, but the Senate could amend Rule XXII to say that a majority can impose cloture on bills passed during successive sessions only when that would not shorten the original veto. ${ }^{67}$

The issues broached by the prior hypothetical raise the basic question of how long the delay should be when a minority resists a vote on final passage. There is nothing magical about using one year as the limit. I am simply borrowing that figure from the procedure used in the House of Lords and the House of Commons, which is discussed in the next section. Since the Senate often stands in recess for a month, the cloture rule could not be that short. ${ }^{6}$ Likewise, a veto longer than a year would require a majority to move something to the floor during the first half of a Congress to avoid a filibuster, which would be a considerable burden. In the final analysis, there is room for experimentation on this question. The 1911 Parliament Act, which overhauled the suspensory veto of the Lords, set that period of delay at two years for most bills. ${ }^{69}$ It was not until 1949 that this limit was lowered to one..$^{70}$ Let us turn to how Parliament reached this equilibrium, as a way of putting my proposal into a broader context.

\section{B. Drawing on the British Parliamentary Experience}

The fight between the House of Commons and the House of Lords over the role that the latter should play in Parliament echoes many themes in the cloture debate. In both cases, the argument for maintaining a strong countermajoritarian force in a legislature was largely procedural, but over time this idea was undermined by its transformation into a mostly substan-

\footnotetext{
${ }^{67}$ In other words, the Senate should not be able to pass a bill in December of one Congress and reenact it in January of the following one if a minority objects. The Parliament Act of 1949 provides that most bills passed in successive sessions by the House of Commons (without the assent of the Lords) become law even if that happens in different parliaments. See Parliament Act, 1949, 12, 13 \& 14 Geo. 6, c. $103, \S 1$ (U.K.). A nomination could be handled along similar lines, but the President would have to nominate the candidate again before the Senate could put that person on the executive calendar.

${ }^{68}$ Otherwise, that would be tantamount to majority cloture if the matter were scheduled strategically. Of course, the time limit could be calculated in terms of hours of debate or days in session, but that would be more complex.

${ }^{69}$ See Parliament Act, 1911, $1 \& 2$ Geo. 5, c. 13, § 2(1) (U.K.). Technically, the suspensory veto was two years and one month, as the Lords were given a month to act when the bill was passed by the House of Commons. See Jenkins, supra note $\ddagger$, at 130 (describing the substance of what became the Act).

${ }^{70}$ See JENKINS, supra note $\ddagger$, at 273-74 (stating that the proposal to reduce the suspensory veto was made, in part, to expedite the nationalization of the steel industry after World War II).
} 
tive rule. The end result was that the Lords' veto was downgraded from absolute to suspensory, which is exactly what should happen in the Senate.

Prior to 1832, the unelected House of Lords was the dominant house of Parliament. ${ }^{71}$ In large part, its dominance stemmed from the fact that individual Lords often controlled who was elected to the Commons within their fiefdoms. ${ }^{72}$ Furthermore, virtually all bills required the Lords' assent to become law. ${ }^{73}$ All of this changed with the enactment of the Reform Act of 1832, which expanded suffrage and reapportioned the boroughs represented in the Commons. ${ }^{74}$ Not surprisingly, the Lords fought against this bill and agreed only when the Crown threatened to swamp the chamber with new peers who would vote for reform. ${ }^{75}$

In the wake of this catastrophic defeat, the Lords needed a theory to justify why it made sense to vest an unelected body with the power to block legislation passed by elected representatives, and their answer was that retaining a check-and-balance would produce more thorough deliberation. ${ }^{76}$ Instead of letting the majority of the Commons legislate unilaterally, the

71 Traditionally, the peers that made up the House of Lords were temporal (hereditary aristocrats), spiritual (the Anglican bishops), and, at a much later point, legal (the Law Lords). In 2009, the judicial function of the chamber came to an end with the creation of a British Supreme Court. See Constitutional Reform Act, 2005, c. 4, §§ 23-60 (U.K.).

The Lords use some quirky procedures. For example, instead of voting "yes" or "no," they vote "content" or "not content." See JenKins, supra note $\ddagger$, at 265 (describing the vote on the Parliament Act of 1911). The chamber can also cut off a member's speech in progress by approving a motion that "the noble Lord be no longer heard," which is definitely different from the Senate.

72 See BAGEHOT, supra note 12, at xxv (stating that before 1832 "[b]y their commanding influence in many boroughs and counties the Lords nominated a considerable part of the Commons"); Rivka Weill, Evolution vs. Revolution: Dueling Models of Dualism, 54 AM. J. COMP. L. 429, 439 (2006) ("The House of Lords indirectly controlled the House of Commons, primarily by determining its composition.").

73 The only exception involved revenue bills, as custom held that the Lords should defer to the House of Commons. See 1 William Manchester, The LASt Lion: Winston SPencer Churchill 407 (1983) ("[S]ince 1660 money matters, by custom, had been left to the commoners."). The special convention for budget matters (before and after 1911) mirrors the reconciliation procedure in the Senate for the budget, under which Rule XXII does not apply. See supra note 3.

${ }^{74}$ See Reform Act of 1832, 2 \& 3 Will. 4, c. $45 \S \S$ I-XVII (Eng.); Reform Act of 1832, 2 \& 3 Will. 4, c. $65 \S \S$ I, IV (Scot.); Reform Act of 1832, 2 \& 3 Will. 4, c. 88 (Ir.); BAGEHOT, supra note 12, at xxv ("By the Act of 1832 this was much altered. The aristocracy and the gentry lost their predominance in the House of Commons; that predominance passed to the middle class. The two Houses then became distinct, but then they ceased to be co-equal.").

75 See Weill, supra note 72, at 455 (quoting the Prime Minister during the debate on the Reform Act, who explained that without the threat of Lords-packing "this country is placed entirely under the influence of an uncontrollable oligarchy").

76 See BAGEHOT, supra note 12, at 100 ("Since the Reform Act the House of Lords has become a revising and suspending House. It can alter Bills; it can reject Bills on which the House of Commons is not yet thoroughly in earnest-upon which the nation is not yet determined."); cf. JENKINS, supra note $\ddagger$, at 94 (quoting a speech by Prime Minister Lloyd George in 1909 in which he asked why "500 men, ordinary men chosen accidentally from among the unemployed, override the judgment- the deliberate judgment — of millions of people who are engaged in the industry which makes the wealth of the country" (quoting Mr. Lloyd George at Newcastle, TiMES (London), Oct. 11, 1909, at 6)). 
Lords would amend bills, slow the process down, and provide breathing space for reflection. ${ }^{77}$ They could also reject bills and require the Commons to pass them again to test the elected majority's resolve. And on matters of grave concern, a steadfast rejection would force a general election that gave voters a chance to decide if a proposal by the Commons deserved support. ${ }^{78}$ A norm evolved that if the Commons approved the controversial bill again after the election, then the Lords would cease their resistance. ${ }^{79}$ In effect, the House of Lords enforced a "second-look" doctrine that was intended to assess preference intensity but conceded the power of the majority to rule in the end. ${ }^{80}$

At the end of the nineteenth century, however, this procedure came under attack because the veto of the House of Lords was seen more and more as a substantive impediment. The problem was that there were far more Tories than Liberals in the Lords. As one observer explained:

When the Conservative Party is in power, ... there is practically no House of Lords: it takes whatever the Conservative Government brings it from the House of Commons without question or dispute; but the moment a Liberal Government is formed, this harmless body assumes an active life, and its activity is entirely exercised in opposition to the Government. ${ }^{81}$

The British public could accept an aristocratic veto on behalf of deliberative democracy or fundamental rights, but that power became illegiti-

\footnotetext{
77 See BAGEHOT, supra note 12, at 115 (“[T] he constitution of the House of Lords only guards against a single error- that of too quick change.”); cf. JENKINS, supra note $\ddagger$, at 200 (stating that the Tories were opposed to "Single-Chamber tyranny").

${ }^{78}$ See Weill, supra note 72, at 444 (quoting Lord Salisbury's view that "[i]t may be that the House of Commons in determining the opinion of the nation is wrong, and if there are grounds for entertaining that belief, it is always open to [the House of Lords], and indeed it is the duty of this House, to insist that the nation shall be consulted"). For example, in 1869 the Lords rejected a bill to disestablish the Irish Church and only reversed course after a general election returned the Government to power. See id. at 441.

79 See BAGEHOT, supra note 12, at xxvii ("[T] he House of Lords must yield whenever the opinion of the Commons is also the opinion of the nation, and when it is clear that the nation has made up its mind."); see also Albert VenN Dicey, Introduction to the StUdy of THE LAW of THE CONSTITUTION 375 (2010) (1902) (“"TThe point at which the Lords must yield or the Crown intervene is properly determined by anything which conclusively shows that the House of Commons represents on the matter in dispute the deliberate decision of the nation.").

${ }^{80}$ See BAGEHOT, supra note 12, at 100 ("Their veto is a sort of hypothetical veto. They say, We reject your Bill for this once, or these twice, or even these thrice: but if you keep on sending it up, at last we won't reject it."). For a thoughtful discussion of second-look doctrines, see Guido Calabresi, Antidiscrimination and Constitutional Accountability (What the Bork-Brennan Debate Ignores), 105 HARV. L. REV. 80, 104-08 (1991). While the House of Lords was not an elected body, the chamber did use a majority voting rule for its own actions.

81 JENKINS, supra note $\ddagger$, at 34 (quoting Memorandum from Lord Rosebery to the Queen (Apr. 7, 1984), reprinted in MARQUESS OF CREWE, 2 LORD ROSEBERY 451-54 (1931))); see id. at 24 (noting that in 1906 only 88 of the 602 peers were self-identified Liberals, while 355 called themselves Tories).
} 
mate once it was used as a partisan tool. ${ }^{82}$ This feeling was captured by Prime Minister David Lloyd George's insult that the Lords were a tool of the Opposition Leader in the Commons, Arthur Balfour, and not a constitutional guardian. ${ }^{83}$ The last straw came from 1906 to 1911, when Liberal majorities (returned by three separate general elections) could not get their program through the Lords. ${ }^{84}$ Consequently, the Commons passed the Parliament Act of 1911, backed by another threat of Lords-packing from the Crown, providing that most bills passed by three consecutive sessions of the Commons would become law without the approval of the Lords ${ }^{85}$

There are several parallels between this reform of Parliament and the evolution of Rule XXII in the Senate. First, both cases offered a procedural reason for originally denying the elected majority the right to act. ${ }^{86}$ A procedural argument was persuasive because many institutions in a legislature, such as the requirement that a committee approve a bill, are not strictly majoritarian and yet are useful for fostering debate. Second, the Senate and the House of Lords both established a custom that allowed a determined majority to work its will. ${ }^{87}$ Third, that norm collapsed as the minority veto

${ }^{82}$ See id. at 44 (quoting Prime Minister Henry Campbell-Bannerman's speech to the Commons in 1906, in which he said: "It is plainly intolerable, Sir, . . that a Second Chamber should, while one party in the State is in power, be its willing servant, and when that party has received an unmistakable and emphatic condemnation by the country, the House of Lords should then be able to neutralize, thwart, and distort the policy which the electors have approved"). There is a parallel here with those who prefer to defend judicial review on the ground that it is "representation-reinforcing" and not substantive. See e.g., John HART Ely, DEMOCRACY AND Distrust: A THEORY OF JUdicial REVIEW (1980).

83 See supra epigraph accompanying note $\ddagger$; see also MANCHESTER, supra note 73, at 410-11 (quoting Churchill's view that the Lords was "a miserable minority of titled persons who represent nobody, who are responsible to nobody and who only scurry up to London to vote in their party interests, their class interests and in their own interests").

84 See Weill, supra note 72, at 442 ("Two consecutive elections during the same year, 1910, were needed to demonstrate clear popular endorsement of the Parliament bill.”); see also JENKINS, supra note $\ddagger$, at 19 (describing the Liberal win of 1906); id. at 107-20 (discussing the first general election of 1910); id. at 185-93 (describing the second election campaign of 1910); MANCHESTER, supra note 73, at 407 (explaining that in this period the Lords rejected the Liberal education bill, voting bill, land reform bill, and temperance bill).

85 See Parliament Act, 1911, 1 \& 2 Geo. 5, c. 13, § 2(1) (U.K.); JENKINS, supra note ‡, at 219 (quoting Prime Minister H.H. Asquith's letter stating that "should the necessity arise, the Government will advise the King to exercise his Prerogative to secure the passing into Law of the [Parliament Act of 1911] in substantially the same form in which it left the House of Commons, and His Majesty has been pleased to signify that he will consider it his duty to accept and act on that advice").

${ }^{86}$ Of course, prior to 1832 , the legitimacy of the Lords was based on the substantive ground that aristocrats were superior to regular people, but that rationale need not concern us here. And I am not suggesting that the current cloture rule is as hostile to majority rule as having a powerful unelected second chamber of Parliament. The point is simply that some relevant comparisons can be made between the two examples.

${ }^{87}$ Moreover, in both cases that norm was (imperfectly) sustained by the credible threat of a rule change to end obstruction. In the Senate, that could be done through a ruling of the presiding officer, and in the House of Lords the lever was Lords-packing. The problem in both cases was that the majority needed the cooperation of a third-party wild card (the Vice President in the Senate or the Crown in Parliament). 
was increasingly seen as substantive and illegitimate ${ }^{88}$ In Britain, the solution to an obstructionist minority was a suspensory veto. ${ }^{89}$

The current practice under Rule XXII is analogous to the discredited power that the Lords held prior to 1911, but in some respects it is worse. One could say, for example, that a consistent refusal to vote for cloture in the Senate lets voters decide whether or not a particular bill should pass, which is how the Lords explained its obstructionism. ${ }^{90}$ Of course, since only one-third of the Senate is up for election in any particular cycle, that appeal to the vox populi is muffled compared to what occurs in the House of Commons, where all members stand for election every time. Put another way, there is no custom holding that if the party backing a filibustered bill retains its Senate majority after an election, then the minority will relent.

In sum, adopting the settlement that Parliament reached - a temporary veto for the House of Lords designed to further discussion while restricting minority obstruction - would also be the best reform for cloture. The question is, how can reformers convince the Senate to change Rule XXII?

\section{MAKING THE SenAte SeE THE LiGHT}

This Part explores how the Senate could be encouraged to support filibuster reform. A campaign spearheaded by sympathetic senators and assisted by the President is necessary but might not be sufficient. ${ }^{91}$ The Senate is understandably proud of its culture and is unlikely to change unless other elected institutions act to supplement a popular outcry. Fortunately, there are some precedents of external forces causing the Senate to abolish privileges held by its minority.

\footnotetext{
88 One distinction is that the House of Lords was considered flagrantly partisan by the time the 1911 Parliament Act was passed, whereas the Senate filibuster is not exclusively the domain of one party. Nevertheless, the change from a restrained procedural instrument into an aggressive substantive one was the same for both chambers.

${ }^{89}$ In addition to the advantages of a temporary veto mentioned above, the House of Lords can still amend bills to slow the process down and spark more debate. It can also reject a bill and test the will of the Government by making it pass the bill again. And the Government's decision to bring a measure forward in the final year of a Parliament means that there is a risk that the bill will not become law, as a defeat at the polls might bring a new party into power. What the Lords cannot do is stop an elected majority in the Commons from getting its way when the matter is a high priority.

90 See supra text accompanying notes 76-80.

91 A campaign against the filibuster mounted by President Wilson led to the adoption of the original cloture rule. See BuRDETTE, supra note 18, at 121 ("The Senate of the United States is the only legislative body in the world ... which cannot act when its majority is ready for action.... The remedy? There is but one remedy. The only remedy is that the rules of the Senate shall be so altered that it can act." (quoting Text of the President's Statement to the Public, N.Y. TIMES, Mar. 5, 1917, at 1)); Gold \& Gupta, supra note 7, at 219 (describing the sharp public reaction against the filibuster of the Armed Ship Bill in 1917). Given that this rule did little to change Senate practice, though, the success of that campaign is open to question.
} 


\section{A. Native Americans, Elections, and Treaties}

There are at least three significant cases when the Senate was forced to eliminate some internal minority rights ${ }^{92}$ : (1) the conduct of Native American policy in the nineteenth century, (2) the ratification of the Seventeenth Amendment in the 1910s, and (3) the development of the congressionalexecutive agreement during World War II. Each of these examples is addressed in turn.

1. Ending the Use of Tribal Treaties.-Prior to the Civil War, the federal government dealt with the Native American tribes via treaties negotiated by the President and ratified by two-thirds of the Senate. ${ }^{93}$ The House of Representatives became frustrated with its exclusion from tribal policy by the $1860 \mathrm{~s}$, in part due to institutional pride and also because the treaty system led to massive corruption. ${ }^{94}$ As one representative explained, "if there is any one thing known to the country and to this House it is that the whole Indian department, in its management, has become utterly rotten, utterly corrupt," and thus something should be done to stop "the plunder and robbery that is going on under the cover of the treaty-making power." 95 One Senator responded that the House possessed "no legitimate power whatever over the subject of Indian treaties any more than it has over treaties with foreign Governments" and that the Senate should not give in to demands that this authority be shared. ${ }^{96}$

After several years of wrangling on this issue, the House took the drastic action of refusing to appropriate any money to implement new tribal treaties. ${ }^{97}$ Without funding, and with no power to force the House to pro-

\footnotetext{
92 None of these precedents involved internal rule changes, although on the question of treaties one could say that the Senate's interpretation of its own rules was transformed.

93 See Antoine v. Washington, 420 U.S. 194, 202 (1975) ("For nearly a century the Executive Branch made treaty arrangements with the Indians 'by and with the Advice and Consent of the Senate[.]' Although the House appropriated money to carry out these treaties, it had no voice in the development of substantive Indian policy reflected in them." (citation omitted)); GERARD N. MAGLIOCCA, ANDREW JaCKSON AND THE CONSTitution: The Rise AND Fall of Generational Regimes 69 (2007) (describing the Senate's debate on the Treaty of New Echota, which legitimized President Jackson's plan to remove the Cherokee Nation along the "Trail of Tears").

94 See Robert Winston MARdock, The ReFormers AND the AMERICAN INDIAN 74 (1971) (stating that in 1870 "the House brought attention to four Indian treaties, then in the Senate, that had granted large areas of Kansas and Nebraska Indian reservations to railroad companies at ridiculously low prices"); see also 1 Francis Paul Prucha, The Great Father: The United States Government AND THE AMERICAN INDIANS 530 (1984) ("The most celebrated case was a treaty signed with the Osages in 1868 by which eight million acres of land was to be sold to railroad interests at about twenty cents an acre.").

95 CONG. Globe, 41 st Cong., 1st Sess. 166 (1869) (statement of Rep. Lawrence).

96 Cong. Globe, 41st Cong., 2d Sess. 2517 (1870) (statement of Sen. Davis).

97 See Cong. Globe, 41st Cong., 1st Sess. 166 (1869) (statement of Rep. Axtell) ("I would stop at once the appropriations of money to carry out these pretended treaties."); see also Antoine, 420 U.S. at 202 ("After further unsuccessful House attempts to enter the field of federal Indian policy, the House refused to grant funds to carry out new treaties.”); $c f$. CONG. GLOBE, 41st Cong., 1st Sess. 167 (1869)
} 
vide any, the Senate capitulated in 1871 and passed a statute stating that "no Indian nation or tribe within the territory of the United States shall be acknowledged or recognized as an independent nation, tribe, or power with whom the United States may contract by treaty." ${ }^{98}$ Thus, the spending strike by the House diminished the Senate's authority as a whole and the power of one-third of the Senate to influence Native American policy by blocking a proposed treaty.

2. The Seventeenth Amendment.-The Constitution had provided that senators would be chosen by state legislatures, but by the late nineteenth century, Populists and Progressives were clamoring for direct Senate elections. ${ }^{99}$ Starting in 1894, the House of Representatives responded by repeatedly passing a constitutional amendment to this effect, but the Senate declined to even bring the proposal to the floor. ${ }^{100}$ Supporters of reform pushed through changes in state election law (such as party primaries and the use of nonbinding ballot initiatives that let voters express their general election preferences on Senate candidates) that increased the influence of voters over the selection process. ${ }^{101}$ But these revisions in state law alone were not going to convince two-thirds of the Senate to change its attitude.

Confronted by this obstacle, proponents of direct election of senators tried to get state legislatures to summon a constitutional convention to submit the proposal directly to the states. ${ }^{102}$ Thirty-one legislatures, one short of the two-thirds needed to convene an Article V convention at the time,

(statement of Rep. Julian) ("I want to remind the gentleman that this House has repeatedly declared that this Indian treaty policy is unwarranted by the Constitution, and if he will lecture the Senate, which has utterly disregarded our action on this subject, he will talk to the body that needs enlightenment.").

98 Act of Mar. 3, 1871, ch. 120, 16 Stat. 544, 566 (codified at 25 U.S.C. $\$ 71$ (2006)); see Antoine, 420 U.S. at 202 ("Finally, the Senate capitulated and joined the House in passage of the 1871 Act as a rider to the Indian Appropriation Act of 1871.”).

99 See U.S. ConST. art. I, § 3, cl. 1 ("The Senate of the United States shall be composed of two Senators from each State, chosen by the Legislature thereof ...."), amended by U.S. CONST. amend. XVII; DAVID E. KYVIG, EXPLICIT AND AUTHENTIC ACTS: AMENDING THE U.S. CONSTITUTION, 17761995, at 208-09 (1996).

100 See Walter Clark, The Next Constitutional Convention of the United States, 16 YALE L.J. 65, 72 (1906) ("Five times has a bill, proposing such amendment to the Constitution, passed the House of Representatives by a practically unanimous vote, and each time it has been lost in the Senate; but never by a direct vote. It has always been disposed of by the chloroform process of referring the bill to a committee, which never reports it back, and never will.").

101 See AKHIL ReEd AMAR, AMERICA's CONSTITUtion: A BIOGRAPHy 411-12 (2005) (discussing these efforts).

102 See U.S. CONST. art. V (stating that Congress, "on the Application of the Legislatures of two thirds of the several States, shall call a convention for proposing Amendments"); see also RALPH A. Rossum, Federalism, the Supreme Court, and the Seventeenth Amendment: The Irony of Constitutional Democracy 193 (2001) ("In 1900, the Pennsylvania legislature took the decisive step of suggesting to the states a coordinated effort to demand a convention; believing that the Senate would not act until two-thirds of the states forced it to do so, it sent to all the states a copy of its convention petition and encouraged them to submit one as well."). 
embraced the proposal. ${ }^{103}$ Faced with pressure from the very legislatures that elected them, the Senators fell into line and passed the amendment in 1912. ${ }^{104}$ Unlike the debate on tribal treaties, there is no evidence that state legislative action against the Senate caused its sudden about-face, but the timing of the change suggests that state legislative action had an effect.

3. Congressional-Executive Agreements in the 1940s.-Returning to the issue of treaty ratification during World War II, the House of Representatives and the President expressed growing frustration with the power of a Senate minority to block international treaties. ${ }^{105}$ There was concern that any attempt to build a stable world order would founder just as it had when a Senate minority rejected the Treaty of Versailles after World War I. ${ }^{106}$ In an echo of the battle over Native American regulation, the House began clamoring for the right to treat international treaties as congressionalexecutive agreements that needed only a majority vote of each House. Senate leaders such as Robert Taft rejected the idea that "anything that can be done by treaty can be done by executive agreement," adding that "[t]he founding fathers felt that the matter of assuming obligations or making promises to do something in the future for foreign nations was of sufficient importance to require that the proposal have the support of two-thirds of the Senators elected to the Senate." 107 As one scholar opined: "When two thirds of the Senate consent to relax any of that body's powers something like the millennium will have dawned." 108

\footnotetext{
103 See C.H. Hoebeke, The RoAd to Mass Democracy: ORiginal Intent AND the SEVENTEENTH AMENDMENT 149 (1995) ("[T]he majority of states were willing to risk opening Pandora's Box for the sake of securing the popular election of senators."); see also RUSSELL L. CAPLAN, CONSTITUTIONAL BRINKSMANSHiP: AMENDING THE CONSTITUTION BY NATIONAL CONVENTION 63-64 (1988) (discussing the state legislative activity). Though state legislatures were, in effect, giving up their own power over the Senate by joining the reform effort, there were valid reasons for this choice. See AMAR, supra note 101, at 412 (noting that deadlocks in state legislatures over the Senate choice frequently kept them from taking up important state business).

104 See Rossum, supra note 102, at 194 ("The fear of a 'runaway' constitutional convention, along with the fact that most senators represented states whose legislatures were on record as favoring direct election of the Senate, proved decisive."); cf. CAPLAN, supra note 103, at 62 (noting that by this time both the national Democratic Party and President Taft supported the change).

105 See H.R. REP. NO. 78-2061, at 6 (1944) ("One-third plus one of the membership of the smaller House of Congress has [the] final decision over what has become one of the paramount problems of government. It is possible that 17 Senators, representing a population of only 4,000,000 people, could thwart the will of the majority of the people and of the States."); ACKERMAN \& GOLOVE, supra note 16, at 70-71 ("Senators representing a tiny fraction of the population could veto initiatives that gained the assent of a popularly elected President and majorities in both Houses.").

106 See, e.g., ACKERMAN \& GOLOVE, supra note 16, at 61 ("When war struck, the Senate's rejection of the League of Nations became a symbol of isolationist irresponsibility.").

10788 CONG. REC. 9276 (1942) (statement of Sen. Taft).

108 Edward S. Corwin, The President: Office AND Powers: History and ANALysis of PRACTICE AND OPINION 235 (1940).
} 
Undaunted by this intransigence, President Roosevelt and his allies in the House settled on a two-pronged strategy to abolish the Senate's treaty monopoly. First, the Administration sent up several popular international agreements for ratification by a majority of each House of Congress and dared the Senate to defeat them as inconsistent with the Treaty Clause. ${ }^{109}$ Second, the House passed a constitutional amendment in 1945 that abolished the Treaty Clause entirely and provided that a majority of each House was needed for ratification. ${ }^{110}$ While the Senate valiantly maintained that it was not relinquishing its constitutional prerogative as it passed a number of binding foreign agreements that the House also voted on, senators eventually stopped challenging the President's power to ignore the traditional treaty ratification process. ${ }^{111}$ While this means of bringing majority rule to the Senate for international treaties did not involve funding restrictions as was the case for tribal treaties, the legal form that emerged in both cases was identical.

\section{B. Unconventional Action and the Filibuster}

Some of the methods used in these prior standoffs with the Senate could be revived to obtain cloture reform, though garnering support for such dramatic actions would be difficult. For example, the House of Representatives could pass a constitutional amendment on cloture, or state legislatures could seek an Article V convention that would accomplish the same objective. But these tools are blunt and impractical. A more sophisticated approach inspired by these earlier confrontations would work better.

One way to pressure the Senate would be for the President and the House to propose new framework statutes, not unlike the budget reconciliation process, that would place strict restrictions on debate about laws on certain subjects. ${ }^{112}$ The Senate would probably resist these initiatives, but forcing senators to take that position visibly and often might lead them to rethink their stance on cloture, as it did for congressional-executive agreements. If the Senate accepted more of these framework laws, it would undercut current cloture practice and give the House and the President an

\footnotetext{
109 See ACKERMAN \& GOLOVE, supra note 16, at 74 ("On the one hand, Roosevelt placated the Senate's sense of prerogative by offering it the United Nations Charter as a treaty. But on the other hand, the Administration aggressively elaborated the existing stock of piecemeal precedents by processing other crucial elements of the post-war order as congressional-executive agreements.").

110 See 91 CONG. REC. 4367 (1945) (stating the vote in favor of the amendment as 288-88); ACKERMAN \& GOLOVE, supra note 16, at 89. In keeping with the Seventeenth Amendment precedent, the Florida Legislature petitioned for an Article V convention on the treaty power. See 91 Cong. ReC. 4965-66 (1945) (discussing this resolution).

111 See ACKERMAN \& GOLOVE, supra note 16, at 73 ("Senators would constantly rise on the floor to explain why the Senate's decision to join with the House to approve particular executive agreements should not be construed as a general capitulation of its sole prerogative to give 'advice and consent.' Nonetheless, the cases began to add up ....").

112 See supra note 3.
} 
opening to impose a suspensory veto on the Senate through similar legislation.

The House could also deny earmarks to senators who support Rule XXII, which mimics how the power of the purse was used to end tribal treaties. There is no way, of course, for the House to discipline the entire Senate by withholding money. Nevertheless, pressuring individual senators is possible (though it would require a single-minded focus that may be tough to achieve given the House's other priorities). The Senate could theoretically retaliate by rejecting House earmarks, but that threat would not be an effective deterrent. The House would only have to single out senators who supported Rule XXII, and those senators would likely have a hard time convincing others to fight back.

In sum, history informs us that the Senate can be coerced into abandoning its supermajority rules through public pressure and a coordinated institutional response. In the cloture context, all of the weapons used in the past - a selective-spending boycott by the House of Representatives, state petitions for a constitutional convention under Article $\mathrm{V}$, a proposed constitutional amendment, and bills seeking to supersede Rule XXII by restructuring debate on specific issues - may be necessary to prevail.

\section{CONCLUSION}

Maintaining the integrity of a tradition often requires change. The custom of extended debate in the Senate was consistent with the principle of majority rule for almost two centuries. But alterations in the size, work, and rules of the Senate have rendered that practice untenable without substantial reform. The best solution lies with an adaptation of the suspensory veto wielded by the House of Lords. Giving forty-one senators the right to delay action for a limited period of time will restore the majority's substantive power while reviving the deliberative benefits long associated with the filibuster. Though the Senate will probably not rush to embrace a revision of its rules, a mix of persuasion and pressure can help to catalyze the change that is necessary to restore the legitimacy of this critical procedural device. I could go on forever about the wisdom of my proposal, but I will now yield the floor. 